\title{
Methylobacterium oryzae sp. nov., an aerobic, pink-pigmented, facultatively methylotrophic, 1-aminocyclopropane-1-carboxylate deaminase- producing bacterium isolated from rice
}

Correspondence

Tong-Min Sa

tomsa@chungbuk.ac.kr

\author{
Munusamy Madhaiyan, ${ }^{1}$ Byung-Yong Kim, ${ }^{2}$ Selvaraj Poonguzhali, ${ }^{1}$ \\ Soon-Wo Kwon, ${ }^{2}$ Myung-Hee Song, ${ }^{2}$ Jeoung-Hyun Ryu, ${ }^{1}$ Seung-Joo Go, ${ }^{2}$ \\ Bon-Sung $\mathrm{Koo}^{2}$ and Tong-Min $\mathrm{Sa}^{1}$
${ }^{1}$ Department of Agricultural Chemistry, Chungbuk National University, Cheongju, Chungbuk 361-763, Republic of Korea \\ ${ }^{2}$ Microbial Genetics Division, National Institute of Agricultural Biotechnology, Rural Development
Administration, Suwon 441-707, Republic of Korea
}

\begin{abstract}
A pink-pigmented, facultatively methylotrophic bacterium, strain $\mathrm{CBMB}^{\top} 0^{\top}$, isolated from stem tissues of rice, was analysed by a polyphasic approach. Strain $\mathrm{CBMB}^{\top} 0^{\top}$ utilized 1aminocyclopropane 1-carboxylate (ACC) as a nitrogen source and produced ACC deaminase. It was related phylogenetically to members of the genus Methylobacterium. 16S rRNA gene sequence analysis indicated that strain $\mathrm{CBMB} \mathrm{O}^{\top}$ was most closely related to Methylobacterium fujisawaense, Methylobacterium radiotolerans and Methylobacterium mesophilicum; however, DNA-DNA hybridization values were less than $70 \%$ with the type strains of these species. The DNA G $+C$ content of strain $\mathrm{CBMB}^{\top} 0^{\top}$ was $70.6 \mathrm{~mol} \%$. The study presents a detailed phenotypic characterization of strain $\mathrm{CBMB} 20^{\top}$ that allows its differentiation from other Methylobacterium species. In addition, strain $\mathrm{CBMB}^{\top} \mathrm{O}^{\top}$ is the only known member of the genus Methylobacterium to be described from the phyllosphere of rice. Based on the data presented, strain $\mathrm{CBMB}^{\top} \mathrm{O}^{\top}$ represents a novel species in the genus Methylobacterium, for which the name Methylobacterium

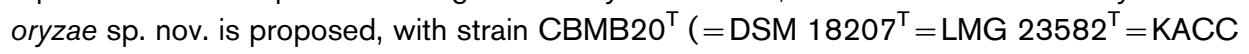
$\left.11585^{\top}\right)$ as the type strain.
\end{abstract}

The genus Methylobacterium includes a group of strictly aerobic, Gram-negative, pink-pigmented, facultatively methylotrophic (PPFM) bacteria characterized by their ability to utilize single-carbon compounds like methanol and formaldehyde via the serine pathway, as well as a wide range of multicarbon growth substrates (Green, 1992). Methylobacterium is classified in the $\alpha 2$ subgroup of the Proteobacteria and presently consists of 22 species with validly published names (Heumann, 1962; Ito \& Iizuka, 1971; Kouno \& Ozaki, 1975; Patt et al., 1976; Rock et al., 1976; Austin \& Goodfellow, 1979; Green \& Bousfield, 1983; Urakami \& Komagata, 1984; Bousfield \& Green, 1985; Green

Abbreviations: ACC, 1-aminocyclopropane 1-carboxylate; PPFM, pinkpigmented, facultatively methylotrophic.

The GenBank/EMBL/DDBJ accession number for the $16 \mathrm{~S}$ rRNA gene sequence of strain $\mathrm{CBMB}^{\top} \mathrm{O}^{\top}$ is $\mathrm{AY} 683045$.

Photomicrographs of strain $\mathrm{CBMB}^{\top}{ }^{\top}, 16 \mathrm{~S}$ rRNA gene sequence similarity data and biochemical reactions that differentiate the novel strains from related species are available as supplementary material in IJSEM Online. et al., 1988; Urakami et al., 1993; Wood et al., 1998; Doronina et al., 2000, 2002; McDonald et al., 2001; Van Aken et al., 2004; Jourand et al., 2004; Anesti et al., 2004; Gallego et al., 2005a, b, c, 2006). Methylobacterium organophilum, the type species, remained the only PPFM bacterium reported with the ability to grow on methane until the description of Methylobacterium populi, a novel methane-utilizing species isolated from poplar trees. Members of the genus Methylobacterium are ubiquitous in nature, detected in soil, freshwater and lake sediments, as well as on other solid surfaces (Corpe \& Rheem, 1989; Lidstrom \& Chistoserdova, 2002), and are known particularly for their close association with plants (Holland \& Polacco, 1994; Lidstrom \& Chistoserdova, 2002; Sy et al., 2005). Associations of members of Methylobacterium with plants range from epiphytic to endophytic and symbiotic relations (Sy et al., 2001; Koenig et al., 2002; Pirttilä et al., 2000; Idris et al., 2006). Possible mechanisms of plantgrowth promotion by Methylobacterium include production of phytohormones, such as indole-3-acetic acid (IAA), cytokinins or vitamins (Basile et al., 1985; Koenig et al., 


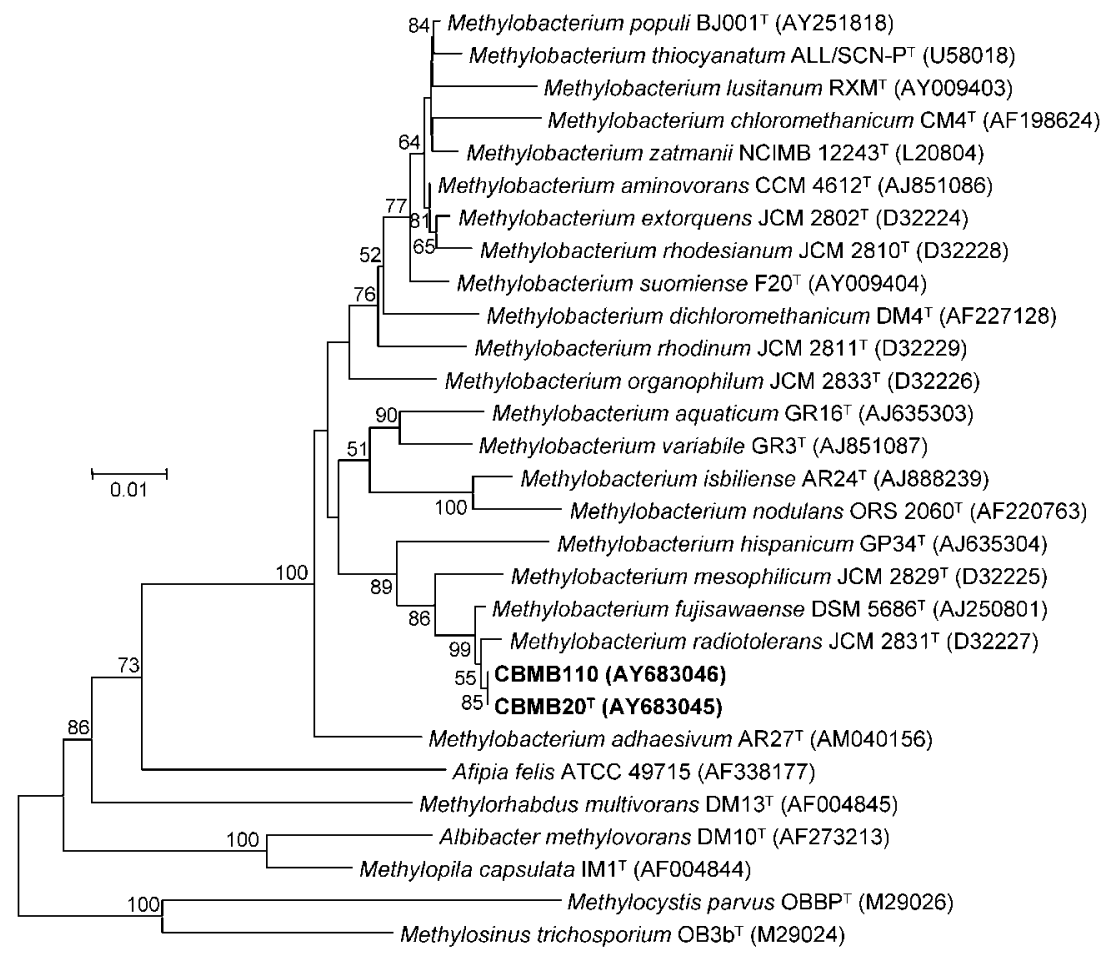

Fig. 1. Phylogenetic tree based on $16 \mathrm{~S}$ rRNA gene sequence comparison showing the position of strains $\mathrm{CBMB}^{\top} \mathrm{O}^{\top}$ and CBMB110 and related species of the genus Methylobacterium. Numbers at nodes indicate percentages of bootstrap support based on a neighbour-joining analysis of 1000 resampled datasets. Values below $50 \%$ are not indicated. Bar, 0.01 substitutions per site.
2002; Trotsenko et al., 2001). In addition, members of Methylobacterium are associated with nitrogen metabolism of plants by means of bacterial urease (Holland \& Polacco, 1992). Methylobacterium strains are able to establish efficient nitrogen-fixing symbioses by nodulating legume roots (Sy et al., 2001) and have been identified as endosymbionts within the buds of Scots pine (Pirttilä et al., 2000). Furthermore, we have reported the enhancement of plant growth in canola by 1-aminocyclopropane-1-carboxylate (ACC) deaminase-producing Methylobacterium strains (Madhaiyan et al., 2006). The data presented in this paper include the formal taxonomic description of a novel species of the genus Methylobacterium for two strains isolated from rice tissues with the ability to produce ACC deaminase.

Strains $\mathrm{CBMB}^{\mathrm{T}}{ }^{\mathrm{T}}$ and $\mathrm{CBMB} 110$ were respectively isolated from surface-disinfected stem and leaf tissues of rice (Oryza sativa L. 'Nam-Pyeoung'). The strains were recovered on ammonium/mineral salts (AMS) medium (Whittenbury et al., 1970) supplemented with filter-sterilized cycloheximide $\left(10 \mu \mathrm{g} \mathrm{ml}^{-1}\right)$ and methanol $(0.5 \% \mathrm{v} / \mathrm{v})$ at $28^{\circ} \mathrm{C}$. The strains were maintained routinely on nutrient agar (NA; Difco) medium, supplemented with $1 \%(\mathrm{v} / \mathrm{v})$ methanol, or on selective AMS medium. Morphological properties were studied according to general protocols (Gerhardt et al., 1994). Scanning electron microscope (SEM) observations were performed on fixed material that was prepared for routine examinations as described by Bozzola \& Russell (1998). Samples were critical-point-dried, mounted on stubs, sputter-coated with gold/palladium and visualized by using a Hitachi S-2500C SEM with GEMINI column equipped with a field-emission electron source.
Chromosomal DNA was extracted and purified from cells cultured on AMS medium as described by Sambrook et al. (1989). 16S rRNA genes were amplified using universal primers fD1 and rP2 (Weisberg et al., 1991) and 16S rRNA gene sequencing was performed by the Big-Dye primer method using an automated DNA sequencer (ABI Prism 310 Genetic Analyzer) as described previously (Brosius et al., 1978; Shima et al., 1994). Phylogenetic analyses were performed using MEGA version 3.1 (Kumar et al., 2004), after multiple alignment of the data by CLUSTAL W (Thompson et al., 1994). Distances were obtained using options according to the Kimura two-parameter model (Kimura, 1980) and clustering was performed using the neighbour-joining (Saitou \& Nei, 1987) method. Bootstrap values from 1000 replications were used to obtain the confidence level of the branches (Felsenstein, 1985).

Nutritional features were determined using the Biolog Microstation (MicroLog-3, 4.01B). The analysis was carried out in Biolog GN2 microtitre plates according to the manufacturer's instructions; the reactions were observed after incubating the plates at $28^{\circ} \mathrm{C}$ for 7 days. Carbonsource utilization tests (excluding Biolog) were performed by using a standard protocol described by Green \& Bousfield (1982). Other physiological and biochemical characteristics were tested using the API ZYM and API 20NE galleries (bioMérieux) following the manufacturer's instructions. Cellular fatty acids were analysed in organisms grown on NA with $1 \%$ methanol $(\mathrm{v} / \mathrm{v})$ for $48 \mathrm{~h}$. The cellular fatty acids were derivatized to methyl esters (Sasser, 1990) and analysed by gas chromatography (Hewlett Packard 6890) using the Microbial Identification System (MIDI; Microbial ID) software package. 
Table 1. Differential carbon-substrate utilization among Methylobacterium species

Utilization of various compounds as sole sources of carbon and energy is shown. Adapted from Green (1992). Species/strains: 1, CBMB20 $^{\mathrm{T}}$; 2, CBMB110; 3, Mtb. radiotolerans (data from Ito \& Iizuka, 1971); 4, Mtb. mesophilicum (Austin \& Goodfellow, 1979); 5, Mtb. fujisawaense (Kouno \& Ozaki, 1975); 6, Mtb. suomiense (Doronina et al., 2002); 7, Mtb. extorquens (Urakami \& Komagata, 1984); 8, Mtb. organophilum (Patt et al., 1976); 9, Mtb. rhodesianum (Rock et al., 1976); 10, Mtb. zatmanii (Rock et al., 1976); 11, Mtb. rhodinum (Heumann, 1962); 12, Mtb. nodulans (Jourand et al., 2004); 13, Mtb. hispanicum (Gallego et al., 2005b); 14, Mtb. populi (Van Aken et al., 2004); 15, Mtb. adhaesivum (Gallego et al., 2006). +, Growth; -, no growth; V, variable; w, weak growth; NA, no data available.

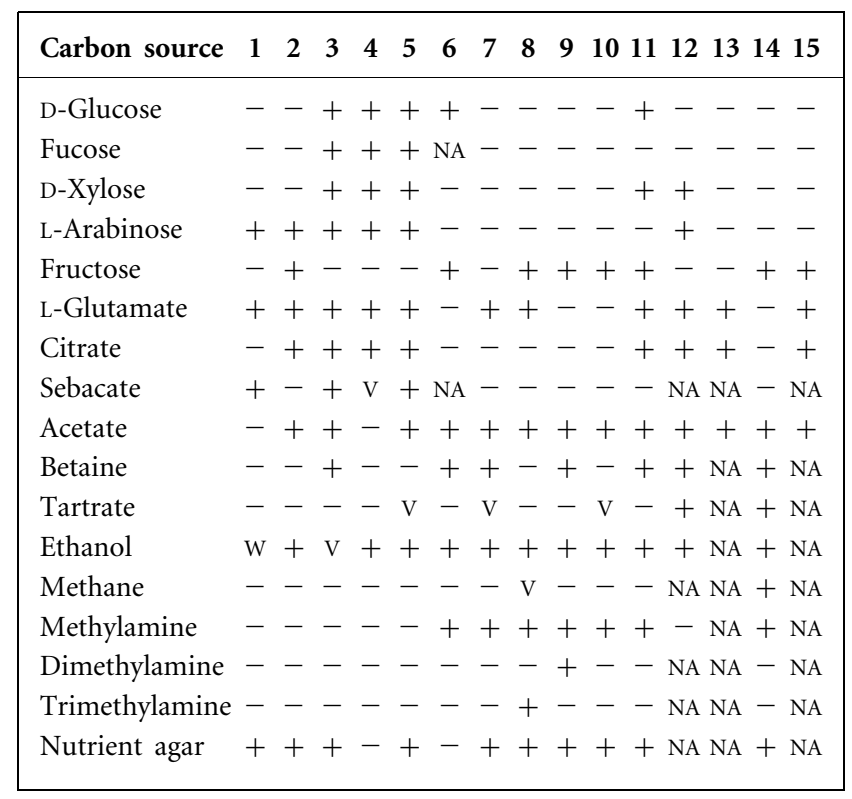

The $\mathrm{G}+\mathrm{C}$ content of genomic DNA was determined by HPLC analysis of individual nucleosides resulting from DNA hydrolysis and dephosphorylation (Mesbah et al., 1989) using a reversed-phase column (Supelcosil LC-18-S; Supelco). DNA-DNA hybridization was carried out following the filter hybridization method as described by Seldin \& Dubnau (1985). Probe labelling was conducted by using the non-radioactive DIG-High Prime system (Roche Diagnostics) and hybridized DNA was visualized using the DIG luminescent detection kit (Roche Diagnostics). Hybridization temperatures were 60 and $65^{\circ} \mathrm{C}$ and DNADNA relatedness was quantified by using a densitometer (Bio-Rad Laboratories).

Strains $\mathrm{CBMB}_{20}^{\mathrm{T}}$ and $\mathrm{CBMB} 110$ were strictly aerobic, Gram-negative, non-spore-forming and formed pink- to red-pigmented colonies. Cells were rod-shaped, frequently branched and occurred singly or in rosettes on solid AMS and NA media. SEM photomicrographs of strain CBMB20 ${ }^{\mathrm{T}}$ are available as Supplementary Figs S1 and S2 in IJSEM Online. The presence of an mxaF gene encoding methanol dehydrogenase required for methanol utilization was examined by PCR using the non-degenerate primers f1003 and r1561 (McDonald \& Murrell, 1997); a product of the expected size (560 bp) was detected, similar to the mxaF genes of other Methylobacterium species. The 16S rRNA gene sequence of strain $\mathrm{CBMB} 20^{\mathrm{T}}$ obtained was a continuous stretch of $1416 \mathrm{bp}$. Sequence similarity calculations and phylogenetic analysis identified the strains as members of the genus Methylobacterium as a separate group and indicated the type strains of Methylobacterium fujisawaense ( $99.1 \%$ similarity), Methylobacterium radiotolerans $(98.0 \%)$ and Methylobacterium mesophilicum $(97.4 \%)$ as the closest relatives (Fig. 1). The 16S rRNA gene sequence similarity matrix is available in Supplementary Table S1.

Phenotypic differences between Methylobacterium species are limited and often rely on utilization of carbon and energy sources (Green \& Bousfield, 1982; Green, 1992). Like other members of the genus, strain $\mathrm{CBMB}_{2} 0^{\mathrm{T}}$ grew on $\mathrm{C}_{1}$ substrates, such as methanol and formate, but not methylamine, trimethylamine or formaldehyde. Strain CBMB $20^{\mathrm{T}}$ differed from its closest relatives in utilization of several carbon sources (summarized in Table 1). Carbonsource utilization, enzyme activities and other biochemical reactions that differentiate the strains from other related species are available as Supplementary Tables S2-S4. The fatty acid profile of strains $\mathrm{CBMB}^{\mathrm{T}}{ }^{\mathrm{T}}$ and $\mathrm{CBMB} 110$ consisted mainly of cis-vaccenic acid $\left(\mathrm{C}_{18: 1} \omega 7 c\right)$ and octadecanoic acid (stearic acid, $\mathrm{C}_{18: 0}$ ) (Table 2).

Strains $\mathrm{CBMB} 20^{\mathrm{T}}$ and $\mathrm{CBMB} 110$ utilize ACC as a nitrogen source, and the presence of ACC deaminase activity in cellfree extracts and the lowering of ethylene levels and promotion of root elongation in canola seedlings under gnotobiotic conditions have been reported elsewhere (Madhaiyan et al., 2006). This particular ability has not been tested among other members of the genus. The type strains of the closely related $M t b$. fujisawaense, $M t b$. radiotolerans and $M t b$. organophilum were tested by preliminary plate assays on AMS medium spread with $30 \mu \mathrm{mol}$ ACC as a nitrogen source, and the results revealed that all three strains are positive for ACC deaminase activity. The presence of ACC deaminase in bacteria plays an important role in plant growth promotion; the bacterial cells act as a sink for ACC, the immediate biosynthetic precursor of ethylene, thereby lowering plant ethylene levels and decreasing the negative effects of various environmental stresses (Stearns et al., 2005). The presence of ACC deaminase in various bacterial genera has been reported previously (Penrose \& Glick, 2001; Belimov et al., 2001).

The DNA $\mathrm{G}+\mathrm{C}$ contents of strains $\mathrm{CBMB}^{\mathrm{T}}{ }^{\mathrm{T}}$ and CBMB110 are respectively 70.6 and 69.2 mol\%. DNADNA reassociation performed to confirm the species status of the novel isolates in relation to their closest phylogenetic neighbours showed $88.63 \%$ relatedness, confirming the close relationship between the two strains. However, the type strains of closely related Methylobacterium species 
Table 2. Cellular fatty acid compositions of strains $\mathrm{CBMB}^{\top} \mathrm{O}^{\top}$ and $\mathrm{CBMB} 110$ and related species of the genus Methylobacterium

Species/strains: 1, CBMB20 ${ }^{\mathrm{T}}$; 2, CBMB110; 3, Mtb. fujisawaense KACC $10744^{\mathrm{T}} ; 4$, Mtb. hispanicum DSM 16372 ${ }^{\mathrm{T}}$; 5, Mtb. mesophilicum DSM $1708^{\mathrm{T}}$; 6, Mtb. organophilum DSM $760^{\mathrm{T}}$; 7, Mtb. radiotolerans DSM $1819^{\mathrm{T}}$ (data in columns $1-7$ from this study); 8, Mtb. populi (data from Van Aken et al., 2004); 9, Mtb. suomiense (Doronina et al., 2002); 10, Mtb. lusitanum (Doronina et al., 2002); 11, 'Mtb. goesingense' (Idris et al., 2006). Values are percentages of total fatty acids. Fatty acids representing less than $0.3 \%$ in all strains were omitted. ND, Not detected; NR, not reported; ECL, equivalent chain length.

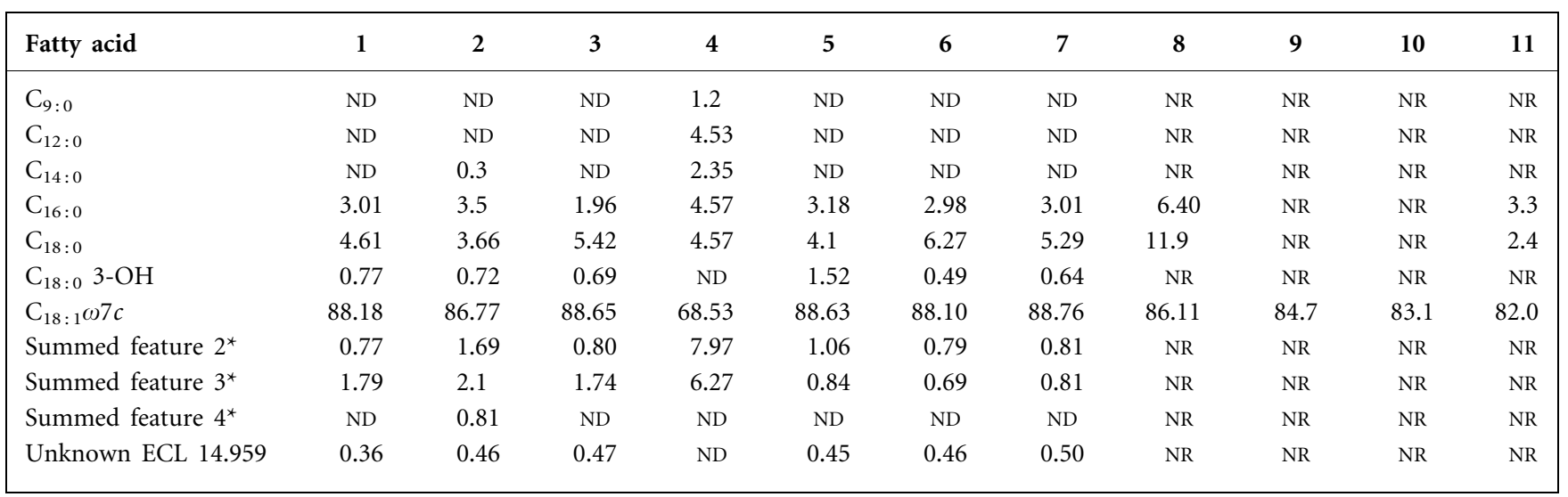

${ }^{*}$ Summed features represent groups of two or three fatty acids that could not be separated by GLC with the MIDI system. Summed feature 2 contained iso- $\mathrm{C}_{16: 1} \mathrm{I}$ and/or $\mathrm{C}_{14: 0} 3-\mathrm{OH}$; summed feature 3 contained $\mathrm{C}_{16: 1} \omega 7 \mathrm{c}$ and/or iso- $\mathrm{C}_{15: 0}$ 2-OH; summed feature 4 contained iso- $\mathrm{C}_{17: 1} \mathrm{I}$ and/or anteiso- $\mathrm{C}_{17: 0} \mathrm{~B}$.

showed $42.09-63.09 \%$ relatedness with $\mathrm{CBMB} 20^{\mathrm{T}}$, indicating that strain $\mathrm{CBMB} 20^{\mathrm{T}}$ can be separated from other members of the genus Methylobacterium (Table 3). These results indicate that strain $\mathrm{CBMB} 20^{\mathrm{T}}$ does not belong to any of these species when the recommendation of a threshold value of $70 \%$ DNA-DNA relatedness for species definition is considered (Wayne et al., 1987).

The 16S rRNA gene sequence similarity data, DNA-DNA hybridization values and phenotypic characteristics allowed strains CBMB20 ${ }^{\mathrm{T}}$ and CBMB110 to be separated from other members of the genus Methylobacterium. Strain $\mathrm{CBMB}_{2} 0^{\mathrm{T}}$ is proposed as the type strain of a novel Methylobacterium species, for which the name Methylobacterium oryzae sp. nov. is proposed.

Table 3. DNA-DNA hybridization between strain CBMB20 ${ }^{\top}$ and its closest relatives

\begin{tabular}{|lc|}
\hline Strain & $\begin{array}{c}\text { DNA-DNA hybridization } \\
\text { with strain CBMB20 }\end{array}$ \\
\hline CBMB20 & (\%)
\end{tabular} \mid \begin{tabular}{cc}
$\mathrm{T}$ & 100.00 \\
CBMB110 & 88.63 \\
Mtb. fujisawaense KACC $10744^{\mathrm{T}}$ & 42.09 \\
Mtb. mesophilicum DSM $1708^{\mathrm{T}}$ & 54.51 \\
Mtb. radiotolerans DSM $1819^{\mathrm{T}}$ & 63.09 \\
\hline
\end{tabular}

\section{Description of Methylobacterium oryzae sp. nov.}

Methylobacterium oryzae (o.ry'zae. L. gen. n. oryzae of rice, from which the type strain was isolated).

Cells are strictly aerobic, Gram-negative, non-spore-forming, motile rods $(0.60-0.80 \times 2.10-2.75 \mu \mathrm{m})$, occurring singly, in pairs or in rosettes. Colonies are pink to red, convex and translucent with regular edges, slow-growing and $0.2-1.2 \mathrm{~mm}$ in diameter after $96 \mathrm{~h}$ at $28^{\circ} \mathrm{C}$ on AMS. Growth occurs on NA and Luria-Bertani, R2A, PYG, succinate, glycerol-peptone and plate count agars. Growth occurs at $20-30{ }^{\circ} \mathrm{C}$ (optimal temperature $28^{\circ} \mathrm{C}$ ), but not at 4 or $40^{\circ} \mathrm{C}$, and at $\mathrm{pH} 5.0-10.0$ (optimal pH 6.8). No growth in the presence of $2.0 \% \mathrm{NaCl}$ or higher. The pink pigment is water-insoluble and has absorption maxima at 233, 358, 505 and $534 \mathrm{~nm}$ in chloroform/methanol $(1: 1)$. Positive for catalase, oxidase, esterase and leucine arylamidase activities. Weak activity for esterase lipase, valine arylamidase, trypsin, acid phosphatase and naphthol-AS-BI-phosphohydrolase. No activity for pectinase, cellulase, protease or lipase. Indole, methyl red and Voges-Proskauer tests are negative. Gelatin, starch, lipid, casein and aesculin are not hydrolysed. Hydrogen sulfide is not produced. Simmons' citrate test is positive. Nitrate is reduced to nitrite. Methanol, ethanol, Darabinose, $\mathrm{D}$-xylose and fumarate are utilized as sole carbon sources. Does not use sucrose, 2-propanol, 1-butanol, dulcitol, L-lysine, betaine, oxalate, tartrate, salicylate, formaldehyde, methylamine, dimethylamine, trimethylamine, dichloromethane or methane. Ammonium sulfate, 
potassium nitrate, sodium nitrate, ammonium chloride, Lalanine, L-glutamate, L-glutamine, urea, ACC and potassium thiocyanate are utilized as sole nitrogen sources. Does not utilize L-aspartate, glycine, L-tryptophan, methylamine or potassium cyanate. Carbon assimilation tests are positive for L-arabinose, potassium gluconate, adipic acid and malic acid. The intrinsic antibiotic-resistance pattern of the type strain shows high resistance to ampicillin, carbenicillin, nalidixic acid, chloramphenicol and streptomycin and sensitivity to kanamycin, gentamicin, spectinomycin and tetracycline. The following compounds are utilized as sole carbon and energy sources (Biolog): L-arabinose, Dgalactose, pyruvic acid methyl ester, succinic acid monomethyl ester, formic acid, D-galactonic acid, lactone, D-gluconic acid, $\alpha$-, $\beta$ - and $\gamma$-hydroxybutyric acids, $\alpha$ ketobutyric acid, $\alpha$-ketoglutaric acid, $\alpha$-ketovaleric acid, DLlactic acid, malonic acid, propionic acid, D-saccharic acid, sebacic acid, succinic acid, bromosuccinic acid, succinamic acid, L-alaninamide, L-asparagine, L-aspartic acid, L-glutamic acid, L-pyroglutamic acid, glycerol and DL- $\alpha$-glycerol phosphate. Cellular fatty acids are hexadecanoate (palmitic acid; $\mathrm{C}_{16: 0}$ ), $3.01 \%$; cis-7-octadecenoate (cis-vaccenic acid; $\left.\mathrm{C}_{18: 1} \omega 7 c\right), 88.18 \%$; octadecanoate (stearic acid; $\mathrm{C}_{18: 0}$ ), $4.61 \%$; and 3-hydroxyoctadecanoate $\left(\mathrm{C}_{18: 0} 3-\mathrm{OH}\right), 0.77 \%$.

The type strain, $\quad$ CBMB20 $0^{\mathrm{T}} \quad\left(=\mathrm{DSM} \quad 18207^{\mathrm{T}}=\mathrm{LMG}\right.$ $23582^{\mathrm{T}}=$ KACC $11585^{\mathrm{T}}$ ), was isolated from stem tissues of rice (Oryza sativa L. 'Nam-Pyeoung') obtained from Chungbuk Provincial Agricultural Research and Extension Services, Cheongwon ( $36^{\circ} 58^{\prime} \mathrm{N} 127^{\circ} 57^{\prime} \mathrm{E}$ ), Chungbuk, Republic of Korea. The DNA G + C content of strain $\mathrm{CBMB} 20^{\mathrm{T}}$ is $70.6 \mathrm{~mol} \%$.

\section{Acknowledgements}

M.M. and S.P. are indebted to the Korea Research Foundation, Republic of Korea, for a position as invited foreign scientist and $\mathrm{PhD}$ research grants, respectively. The authors also acknowledge support from the Rural Development Administration, Republic of Korea.

\section{References}

Anesti, V., Vohra, J., Goonetilleka, S., McDonald, I. R., Sträubler, B., Stackebrandt, E., Kelly, D. P. \& Wood, A. P. (2004). Molecular detection and isolation of facultatively methylotrophic bacteria, including Methylobacterium podarium sp. nov., from the human foot microflora. Environ Microbiol 6, 820-830.

Austin, B. \& Goodfellow, M. (1979). Pseudomonas mesophilica, a new species of pink bacteria isolated from leaf surfaces. Int J Syst Bacteriol 29, 373-378.

Basile, D. V., Basile, M. R., Li, Q. Y. \& Corpe, W. A. (1985). Vitamin $\mathrm{B}_{12}$-stimulated growth and development of Jungermannia leiantha Grolle and Gymnocolea inflata (Huds.) Dum (Hepaticae). Bryologist 88, 77-81.

Belimov, A. A., Safronova, V. I., Sergeyeva, T. A., Egorova, T. N., Matveyeva, V. A., Tsyganov, V. E., Borisov, A. Y., Tikhonovich, I. A., Kluge, C. \& other authors (2001). Characterization of plant growth promoting rhizobacteria isolated from polluted soils and containing 1-aminocyclopropane-1-carboxylate deaminase. Can J Microbiol 47, 642-652.
Bousfield, I. J. \& Green, P. N. (1985). Reclassification of bacteria of the genus Protomonas Urakami and Komagata 1984 in the genus Methylobacterium (Patt, Cole, and Hanson) emend. Green and Bousfield 1983. Int J Syst Bacteriol 35, 209.

Bozzola, J. J. \& Russell, L. D. (1998). Electron Microscopy, 2nd edn. Sudbury, MA: Jones and Bartlett.

Brosius, J., Palmer, M. L., Kennedy, P. J. \& Noller, H. F. (1978). Complete nucleotide sequence of the $16 \mathrm{~S}$ ribosomal RNA gene from Escherichia coli. Proc Natl Acad Sci U S A 75, 4801-4805.

Corpe, W. A. \& Rheem, S. (1989). Ecology of the methylotrophic bacteria on living leaf surfaces. FEMS Microbiol Ecol 62, 243-250.

Doronina, N. V., Trotsenko, Y. A., Tourova, T. P., Kuznetsov, B. B. \& Leisinger, T. (2000). Methylopila helvetica sp. nov. and Methylobacterium dichloromethanicum sp. nov. - novel aerobic facultatively methylotrophic bacteria utilizing dichloromethane. Syst Appl Microbiol 23, 210-218.

Doronina, N. V., Trotsenko, Y. A., Kuznetsov, B. B., Tourova, T. P. \& Salkinoja-Salonen, M. S. (2002). Methylobacterium suomiense sp. nov. and Methylobacterium lusitanum sp. nov., aerobic, pinkpigmented, facultatively methylotrophic bacteria. Int J Syst Evol Microbiol 52, 773-776.

Felsenstein, J. (1985). Confidence limits on phylogenies: an approach using the bootstrap. Evolution 39, 783-791.

Gallego, V., Garcia, M. T. \& Ventosa, A. (2005a). Methylobacterium hispanicum sp. nov. and Methylobacterium aquaticum sp. nov., isolated from drinking water. Int J Syst Evol Microbiol 55, 281-287.

Gallego, V., Garcia, M. T. \& Ventosa, A. (2005b). Methylobacterium variabile sp. nov., a methylotrophic bacterium isolated from an aquatic environment. Int J Syst Evol Microbiol 55, 1429-1433.

Gallego, V., Garcia, M. T. \& Ventosa, A. (2005c). Methylobacterium isbiliense sp. nov., isolated from the drinking water system of Sevilla, Spain. Int J Syst Evol Microbiol 55, 2333-2337.

Gallego, V., Garcia, M. T. \& Ventosa, A. (2006). Methylobacterium adhaesivum sp. nov., a methylotrophic bacterium isolated from drinking water. Int J Syst Evol Microbiol 56, 339-342.

Gerhardt, P. R., Murray, R. G. E., Wood, W. A. \& Krieg, N. R. (editors) (1994). Methods for General and Molecular Bacteriology. Washington, DC: American Society for Microbiology.

Green, P. N. (1992). The genus Methylobacterium. In The Prokaryotes, 2nd edn, pp. 2342-2349. Edited by A. Balows, H. G. Trüper, M. Dworkin, W. Harder \& K. H. Schleifer. New York: Springer.

Green, P. N. \& Bousfield, I. J. (1982). A taxonomic study of some Gram-negative facultatively methylotrophic bacteria. J Gen Microbiol 128, 623-638.

Green, P. N. \& Bousfield, I. J. (1983). Emendation of Methylobacterium Patt, Cole, and Hanson 1976; Methylobacterium rhodinum (Heumann 1962) comb. nov. corrig.; Methylobacterium radiotolerans (Ito and lizuka 1971) comb. nov. corrig.; and Methylobacterium mesophilicum (Austin and Goodfellow 1979) comb. nov. Int J Syst Bacteriol 33, 875-877.

Green, P. N., Bousfield, I. J. \& Hood, D. (1988). Three new Methylobacterium species: M. rhodesianum sp. nov., M. zatmanii sp. nov., and M. fujisawaense sp. nov. Int J Syst Bacteriol 38, 124-127. Heumann, W. (1962). Die Methodik der Kreuzung sternbildender Bakterien. Biol Zentralbl 81, 341-354 (in German).

Holland, M. A. \& Polacco, J. C. (1992). Urease-null and hydrogenasenull phenotypes of a phylloplane bacterium reveal altered nickel metabolism in two soybean mutants. Plant Physiol 98, 942-948.

Holland, M. A. \& Polacco, J. C. (1994). PPFMs and other covert contaminants: is there more to plant physiology than just plant? Annu Rev Plant Physiol Plant Mol Biol 45, 197-209. 
Idris, R., Kuffner, M., Bodrossy, L., Puschenreiter, M., Monchy, S., Wenzel, W. W. \& Sessitsch, A. (2006). Characterization of Nitolerant methylobacteria associated with the hyperaccumulating plant Thlaspi goesingense and description of Methylobacterium goesingense sp. nov. Syst Appl Microbiol 29, 634-644.

Ito, H. \& lizuka, H. (1971). Taxonomic studies on a radio-resistant Pseudomonas. XII. Studies on the microorganisms of cereal grain. Agric Biol Chem 35, 1566-1571.

Jourand, P., Giraud, E., Bena, G., Sy, A., Willems, A., Gillis, M., Dreyfus, B. \& de Lajudie, P. (2004). Methylobacterium nodulans sp. nov., for a group of aerobic, facultatively methylotrophic, legume root-nodule-forming and nitrogen-fixing bacteria. Int J Syst Evol Microbiol 54, 2269-2273.

Kimura, M. (1980). A simple method for estimating evolutionary rates of base substitutions through comparative studies of nucleotide sequences. J Mol Evol 16, 111-120.

Koenig, R. L., Morris, R. O. \& Polacco, J. C. (2002). tRNA is the source of low-level trans-zeatin production in Methylobacterium spp. J Bacteriol 184, 1832-1842.

Kouno, K. \& Ozaki, A. (1975). Distribution of methanol-utilizing bacteria. In Proceedings of the International Symposium on Microbial Growth on C1 Compounds, pp. 11-21. Osaka, Japan: Society of Fermentation Technology.

Kumar, S., Tamura, K. \& Nei, M. (2004). MEGA3: integrated software for molecular evolutionary genetics analysis and sequence alignment. Brief Bioinform 5, 150-163.

Lidstrom, M. E. \& Chistoserdova, L. (2002). Plants in the pink: cytokinin production by Methylobacterium. J Bacteriol 184, 1818.

Madhaiyan, M., Poonguzhali, S., Ryu, J. H. \& Sa, T. M. (2006). Regulation of ethylene levels in canola (Brassica campestris) by 1-aminocyclopropane-1-carboxylate deaminase-containing Methylobacterium fujisawaense. Planta 224, 268-278.

McDonald, I. R. \& Murrell, J. C. (1997). The methanol dehydrogenase structural gene mxaF and its use as a functional gene probe for methanotrophs and methylotrophs. Appl Environ Microbiol 63 3218-3224.

McDonald, I. R., Doronina, N. V., Trotsenko, Y. A., McAnulla, C. \& Murrell, J. C. (2001). Hyphomicrobium chloromethanicum sp. nov. and Methylobacterium chloromethanicum sp. nov., chloromethaneutilizing bacteria isolated from a polluted environment. Int J Syst Evol Microbiol 51, 119-122.

Mesbah, M., Premachandran, U. \& Whitman, W. B. (1989). Precise measurement of the $\mathrm{G}+\mathrm{C}$ content of deoxyribonucleic acid by highperformance liquid chromatography. Int J Syst Bacteriol 39, 159-167.

Patt, T. E., Cole, G. C. \& Hanson, R. S. (1976). Methylobacterium, a new genus of facultatively methylotrophic bacteria. Int $J$ Syst Bacteriol 26, 226-229.

Penrose, D. M. \& Glick, B. R. (2001). Levels of ACC and related compounds in exudate and extracts of canola seeds treated with ACC deaminase-containing plant growth-promoting bacteria. Can J Microbiol 47, 368-372.

Pirttilä, A. M., Laukkanen, H., Pospiech, H., Myllylä, R. \& Hohtola, A. (2000). Detection of intracellular bacteria in the buds of Scotch pine (Pinus sylvestris L.) by in situ hybridization. Appl Environ Microbiol 66, 3073-3077.

Rock, J. S., Goldberg, I., Ben-Bassat, A. \& Mateles, R. I. (1976) Isolation and characterization of two methanol-utilizing bacteria. Agric Biol Chem 40, 2129-2135.

Saitou, N. \& Nei, M. (1987). The neighbor-joining method: a new method for reconstructing phylogenetic trees. Mol Biol Evol 4, 406-425.
Sambrook, J., Fritsch, E. F. \& Maniatis, T. (1989). Molecular Cloning: a Laboratory Manual, 2nd edn. Cold Spring Harbor, NY: Cold Spring Harbor Laboratory.

Sasser, M. (1990). Identification of bacteria through fatty acid analysis. In Methods in Phytobacteriology, pp. 199-204. Edited by S. Klement, K. Rudolf \& D. Sands. Budapest: Akademiai Kiado.

Seldin, L. \& Dubnau, D. (1985). Deoxyribonucleic acid homology among Bacillus polymyxa, Bacillus macerans, Bacillus azotofixans, and other nitrogen-fixing Bacillus strains. Int J Syst Bacteriol 35, 151-154.

Shima, S., Yanagi, M. \& Saiki, H. (1994). The phylogenetic position of Hydrogenobacter acidophilus based on 16S rRNA sequence analysis. FEMS Microbiol Lett 119, 119-122.

Stearns, J. C., Shah, S., Greenberg, B. M., Dixon, D. G. \& Glick, B. R. (2005). Tolerance of transgenic canola expressing 1-aminocyclopropane-1-carboxylic acid deaminase to growth inhibition by nickel. Plant Physiol Biochem 43, 701-708.

Sy, A., Giraud, E., Jourand, P., Garcia, N., Willems, A., de Lajudie, P., Prin, Y., Neyra, M., Gillis, M. \& other authors (2001). Methylotrophic Methylobacterium bacteria nodulate and fix nitrogen in symbiosis with legumes. J Bacteriol 183, 214-220.

Sy, A., Timmers, A. C. J., Knief, C. \& Vorholt, J. A. (2005). Methylotrophic metabolism is advantageous for Methylobacterium extorquens during colonization of Medicago truncatula under competitive conditions. Appl Environ Microbiol 71, 7245-7252.

Thompson, J. D., Higgins, D. G. \& Gibson, T. J. (1994). CLUSTAL W: improving the sensitivity of progressive multiple sequence alignment through sequence weighting, position-specific gap penalties and weight matrix choice. Nucleic Acids Res 22, 4673-4680.

Trotsenko, Yu. A., Ivanova, E. G. \& Doronina, N. V. (2001). Aerobic methylotrophic bacteria as phytosymbionts. Mikrobiologiia 70, 725736 (in Russian).

Urakami, T. \& Komagata, K. (1984). Protomonas, a new genus of facultatively methylotrophic bacteria. Int J Syst Bacteriol 34, 188-201.

Urakami, T., Araki, H., Suzuki, K. \& Komagata, K. (1993). Further studies of the genus Methylobacterium and description of Methylobacterium aminovorans sp. nov. Int J Syst Bacteriol 43, 504-513.

Van Aken, B., Peres, C. M., Lafferty-Doty, S., Yoon, J. M. \& Schnoor, J. L. (2004). Methylobacterium populi sp. nov., a novel aerobic, pinkpigmented, facultatively methylotrophic, methane-utilizing bacterium isolated from poplar trees (Populus deltoides $\times$ nigra DN34). Int J Syst Evol Microbiol 54, 1191-1196.

Wayne, L. G., Brenner, D. J., Colwell, R. R., Grimont, P. A. D., Kandler, O., Krichevsky, M. I., Moore, L. H., Moore, W. E. C., Murray, R. G. E. \& other authors (1987). International Committee on Systematic Bacteriology. Report of the ad hoc committee on reconciliation of approaches to bacterial systematics. Int $J$ Syst Bacteriol 37, 463-464.

Weisberg, W. G., Barns, S. M., Pelletier, B. A. \& Lane, D. J. (1991). $16 \mathrm{~S}$ ribosomal DNA amplification for phylogenetic study. J Bacteriol 173, 697-703.

Whittenbury, R., Phillips, K. C. \& Wilkinson, J. F. (1970). Enrichment, isolation and some properties of methane-utilizing bacteria. J Gen Microbiol 61, 205-218

Wood, A. P., Kelly, D. P., McDonald, I. R., Jordan, S. L., Morgan, T. D., Khan, S., Murrell, J. C. \& Borodina, E. (1998). A novel pink pigmented facultative methylotroph, Methylobacterium thiocyanatum sp. nov., capable of growth on thiocyanate or cyanate as sole nitrogen sources. Arch Microbiol 169, 148-158. 